\title{
The fiscal benefits of repeated cooperation: coalitions and debt dynamics in 36 democracies
}

\section{DAVID WEISSTANNER}

Institute of Political Science, University of Bern, Switzerland Email: david.weisstanner@ipw.unibe.ch

Pre-print version (March
2016). Published version
available at the Journal of
Public Policy,
https://doi.org/10.1017/
S0143814X16000040

\begin{abstract}
:
Do coalition governments really suffer from short time horizons in fiscal policy-making, as posited by standard political economy models? This article focuses on coalitions which have created high levels of familiarity through shared governing experience in the past and which are likely to cooperate again in future governing coalitions. I argue that such coalitions have incentives to internalize the future costs of debt accumulation and reach credible agreements to balance their constituencies' fiscal preferences. Moreover, sustaining broad coalitions should have electoral advantages to implementing controversial economic reforms, thus resulting with lower debt increases compared not only to less durable coalitions, but also to single-party governments. Comparing 36 OECD/EU democracies between (up to) 1962 and 2013, I estimate the effects of coalitions' cooperation prospects on the dynamics of public debt. The findings indicate that long time horizons can help coalitions to overcome intertemporal coordination problems and to reach specific policy goals.
\end{abstract}

\section{Key words:}

Coalition government, cooperation, political parties, fiscal policy, government debt

\section{Introduction}

Time is a central feature of democracies. Office terms limited through periodical elections confine political time horizons to relatively short segments (Linz 1998). But, under which conditions could politicians and political parties adopt longer time horizons that extend over the next elections? Although many policy reforms depend crucially on long-term orientations of political actors (Jacobs 2011), time perspectives of governments have often been neglected in the literature. In the fiscal policy literature, an implicit assumption is that coalition governments are particularly unable to adopt long-term time perspectives, and therefore, end up with higher indebtedness rates, deficits or government expenditure (Bawn and Rosenbluth 2006; Grilli et al. 1991; Roubini and Sachs 1989; Tsebelis 2002).

However, parties with shared governing experiences in the past have created high levels of familiarity amongst each other, leaving them a substantial chance to cooperate again in the 
same constellation in future governments (Franklin and Mackie 1983; Martin and Stevenson 2001, 2010). Such coalitions should be concerned more strongly about the future costs of today's debt developments, because they may have to face the consequences themselves. Based on these assumptions, this article explores the effects of coalitions' prospects to cooperate in future governments on the development of their debt ratios. If governing parties expect good prospects for future cooperation, they should more credibly be able to refrain from unilateral spending demands for their own constituencies.

This implies that fiscal outcomes under coalitions credibly committing to long-term policy goals should be indiscernible from single-party governments' outcomes, which is in line with a recent study by Bäck and Lindvall (2015). Yet, fiscal policy-making goes beyond veto player and common pool resource problems commonly associated with coalition governments. Coalitions cooperating repeatedly based on their familiarity should also be able to forge broad political support and achieve consensus on electorally contested economic policies because of their ability to spread the costs and blame of reforms across coalition partners (Alexiadou 2013; Katzenstein 1985; Lijphart 2012). As a consequence, coalition governments can be expected to achieve debt outcomes even more favorable than one-party governments, provided they can settle for long-lasting cooperation and adjust their debt preferences under the "shadow of the future” (Lupia and Strøm 2008).

Empirical evidence for this argument derives from a comparison of 36 democracies, OECD and/or EU member states, spanning the time period from 1962 (or since democratization) to 2013. Consistent with comparable studies, “prospective cooperation” is operationalized as a retrospective measure of past cooperation experiences of the current governing parties. The relationship between prospective cooperation and debt development is statistically investigated using time-series cross-sectional regression analysis. The main tests consist of "autoregressive distributed lag” models discerning between short-run and long-run effects. In addition, a government-centered data structure is employed based on cabinets as the unit of observation instead of country-years.

The results show that the longer time perspectives of coalitions with a high chance for prospective cooperation are related to lower debt increases - compared not only to coalitions without durable cooperation patterns (Bäck and Lindvall 2015), but also compared to singleparty governments. Complementing the study by Bäck and Lindvall (2015), I discuss further theoretically relevant factors which condition the impact of coalitions' time horizons: The fiscally beneficial effects of prospective cooperation are particularly pronounced in nonelection years and where fiscal pressure reduces the scope for "pork-barrel politics”. This study 
challenges the implicit assumption of political-economy models that governments' time horizon rarely exceeds the next election. Rather, based on the ability of governments for strategic behavior (König and Wenzelburger 2014; Müller and Strøm 1999), the findings are consistent with new research on the significance of intertemporal considerations in politics (Bejar et al. 2011; Bojar 2015; Hübscher 2015; Jacobs 2011).

This article is organized as follows: The following chapter introduces the theoretical argument; the empirical section explains the operationalization of the variables, the statistical methods, and the results of the multivariate statistical analysis. Some implications of the analysis are discussed in the conclusion.

\section{Government form and debt dynamics}

Multi-party governments have frequently been associated with fiscally less beneficial debt, deficit, or expenditure policy outcomes compared to one-party governments in the literature (for an overview, see Alesina and Perotti 1995). First, early political-economy models diagnosed coalition governments with a “common pool” problem (Roubini and Sachs 1989; Weingast et al. 1981), which is furthermore exacerbated by fragmentation, i.e. a higher number of parties in government. Many fragmented governments have conflicting interests among the coalition partners. Rational government parties prefer to maximize spending for their own constituencies since they do not have to bear the overall costs alone (Bawn and Rosenbluth 2006; Hallerberg and von Hagen 1999; von Hagen and Harden 1995). In other words, coalitions are associated with higher budget deficits because they "externalize" the costs of additional expenditure for their preferred policy fields and want to shift the costs onto other groups within the coalition (Bawn and Rosenbluth 2006, 253-54).

Second, due to their fragmentation, coalition governments have difficulties in adjusting budget deficits because coalition partners shield their preferred policy fields from cutbacks while trying to shift the burden of fiscal adjustments to other coalition partners or external groups (Alesina and Drazen 1991; Roubini and Sachs 1989). The higher number of veto players and the greater ideological distance, compared to one-party governments, thus reduce the ability of coalitions to adjust to economic shocks (Tsebelis 2002, chapter 8).

Third, it has been argued that coalition governments have higher debt ratios because they are more short-lived than single-party governments (Bejar et al. 2011; Grilli et al. 1991). In economic terms, unstable government forms have a higher "discount rate" of the future, i.e. they prefer immediate benefits over future benefits. Therefore, they act "myopically” as they 
overvalue the benefits of present government spending compared with the costs of higher indebtedness ratios in the future (Grilli et al. 1991, 349).

Yet, notwithstanding an abundance of studies, the empirical findings on the effects of the type of government are not uncontested (e.g. de Haan and Sturm 1997; Edin and Ohlsson 1991; Sakamoto 2001). One problem of fragmentation and veto player approaches is their uniform treatment of time horizons. The value of the future could increase for coalition partners expecting to remain in office for longer time periods. This would provide incentives to "internalize" the whole cost of their public policy decisions. Coalition bargaining, in fact, often takes place under the "shadow of the future" with incentives to make credible future agreements (Lupia and Strøm 2008).

A second potential explanation for deviating findings is the debatable characterization of one-party governments as unitary decision-makers while coalitions are seen as heterogeneous decision-makers with divergent preferences that lead to collective action problems (Bäck and Lindvall 2015, 55). However, all parties represent coalitions of conflicting interests of societal groups. For instance, the German CDU is an example for intra-party federalism (Schmid 1990). One reason why parties exist is indeed to become durable coalitions (Aldrich 2011). Why then should the number of parties result in policy differences when several groups in society can be equally represented by both one-party and multi-party governments (Persson et al. 2007, 156)? Possibly, one-party governments are electorally accountable for all policy areas, while voters associate only policy subsets with each coalition party (Bawn and Rosenbluth 2006). However, this argument ignores that collaboration among parties raises their familiarity and facilitates repeated cooperation within the same constellation (Franklin and Mackie 1983), which makes coalitions appear more so as fixed entities over time. The assumption that only coalitions are non-unitary decision-makers becomes uncertain when multi-party governments are not as homogeneous and when coalition parties cooperate more sustainably than commonly assumed.

\section{Introducing time horizons: future cooperation prospects}

These tenuous assumptions make it questionable if all coalitions are actually distinguishable from one-party governments with regard to their time horizons. Coalition governments, I argue, should be even more capable than single-party governments to produce favorable fiscal policy outputs if their longer time horizon through "prospective cooperation" in the future permits them to credibly agree on debt-stabilizing policies. Behind this argument are three assumptions. First, coalitions with a shared past governing experience have higher chances to govern together in the future again, because they are familiar with each other. Second, such 
coalitions are likely to internalize the future costs of indebtedness. Third, broad and durable coalitions can diffuse the electoral risks of contested fiscal policies more effectively than single-party governments.

In detail, the first assumption states that parties in coalition governments see a chance that they might cooperate again in the future. Evidence comes from the coalition formation literature. Parties that regularly cooperated in the past have created high degrees of familiarity among each other (Franklin and Mackie 1983). The shared experiences of past government participation reduce bargaining costs for coalition agreements and go along with reputational benefits (Warwick 1996, 474). Furthermore, parties prefer keeping the same partners, as they know more about each other and are better able to communicate (Bäck and Dumont 2007, 487). Incumbent coalitions with high familiarity therefore have higher chances to form the next government (Martin and Stevenson 2001, 2010). Conversely, the chance for prospective cooperation is reduced with dissention and betraying behavior in the past (Bäck and Dumont 2007, 487; Tavits 2008). All these studies argue that the prospects for future cooperation are decisively influenced by the cooperation behavior in the past. Thus, it is reasonable to assume that prospective cooperation can be assessed through past cooperation patterns. This assumption can be empirically tested by comparing varying retrospective measures of past coalition patterns.

The second assumption of the argument is that parties care about the costs of high future indebtedness levels. Rarely, governments face positive economic shocks and end up with comfortable fiscal situations so they can sustain high budget deficits without constraints. More typically, higher debt ratios bear some undeniable long-term costs for all governments (Alesina and Drazen 1991; Reinhart and Rogoff 2009). Although this does not rule out debt as an economic policy option, it limits unrestricted indebtedness at the cost of future generations for parties expecting future participation in government. Coalitions with prospective cooperation will therefore have to budget these long-term costs and internalize them at some point, i.e. not shift them to external groups or to future governments. This assumption can also be tested empirically because fiscal pressure should moderate the incentive for coalitions to internalize the long-run costs of additional spending.

While repeated participation in government and internalization of the future costs of debt accumulation can also apply to single-party governments, the third assumption concerns a unique characteristic of coalition governments. The literature on consensus democracies (for recent empirical evidence, see: Alexiadou 2013; Armingeon et al. 2015a; Katzenstein 1985; Lijphart 2012; Luebbert 1984) suggests that governments which are able to forge broad 
coalitions with opposition parties and societal actors can more easily agree on electorally contested reforms. Coalitions with good cooperation prospects resemble such broad coalitions because they can support cross-party alliances over extended periods of time. They can gather broader electoral support for a long-term view on debt developments by exploiting opportunities to diffuse blame and responsibility for unpopular policies across coalition partners (Powell and Whitten 1993; Weaver 1986). On the other hand, although coalition governments with longer time horizons can agree on the goal of pursuing fiscal stabilization policies, the process of agreeing on - and implementing - status quo changes may still take a longer time relative to one-party governments due to the multiple veto actors involved (Armingeon et al. 2014; Tsebelis 2002). Yet, accounting for the more difficult process of reaching consensual policy positions, their advantages in including a broader spectrum of political actors into governmental decision-making should enable durable coalitions from keeping debt accumulation under control even better than single-party governments.

Taken together, the causal mechanism of the argument has started from the common observation that, stemming from their fragmentation, coalitions have a "time-inconsistency problem” (Kydland and Prescott 1977) because without future perspectives, some coalition partners have electoral incentives to maximize spending on their preferred policy areas and externalize its costs (Bawn and Rosenbluth 2006). But from a critical examination of these assumptions about coalitions' common pool resource and veto player problems, it follows that coalitions can overcome the time-inconsistency challenge if (a) they expect future cooperation in government, (b) they desire to avoid unreasonably high future debt levels, and (c) they represent broad societal coalitions which minimize electoral risks associated with controversial reforms. In these circumstances, coalition agreements that lead to farsighted fiscal policymaking can be reached more easily because the partners are familiar with each other. Opt-out options - by leaving the coalition or sabotaging agreements with coalition partners - are associated with higher costs because the parties have to consider that their partners would not be likely to cooperate with them anymore in the future in such cases. The "walk-away value" for coalition bargaining (Lupia and Strøm 2008), or, the benefit of the bargaining leader for leaving the bargaining round, diminishes in such situations. The expectation of prospective cooperation therefore leads to a contract-like situation which relies on reciprocal trust and reputation, and which can be the source for credible long-term agreements (Kreps 1990; Majone 1996). This leads to the main hypothesis of this article about the fiscally beneficial effects of prospective cooperation: 
H1: The stronger the prospects for future cooperation of a coalition government, the lower its debt increases compared to less durable coalitions and compared to single-party governments.

With the goal of keeping debt accumulation in check, the credibility advantages of prospective cooperation facilitate a wide range of fiscal policy agreements. Possible examples include the capacity to freeze spending levels on existing levels, maintain deficit and/or debt ratio targets, set growth and employment objectives, agree on fiscal consolidation measures by reducing expenditures or increasing taxes, and commit to strict implementations of fiscal objectives. In practice, we find many instances where coalition parties openly refrain from unilaterally claiming fiscal resources for their own constituencies. For example, the Swedish center-right coalition - the traditional opposition block to the Social Democratic party - governing between 2006 and 2014 committed itself to budget surpluses in both their 2006 and 2010 electoral manifestos. ${ }^{1}$ Grand coalitions in Austria - Christian and Social Democrats share a long history of co-governing - regularly agree on detailed coalition programs, such as a 288-page document for the 2008-2013 term which underlined the goal of a balanced budget with specific measures of fiscal consolidation. ${ }^{2}$ Another instance is Ireland's center-left government of 1994-1997, characterizing itself as a "government of renewal". ${ }^{3}$ Fine Gael and the Labour Party had collaborated three times between 1973 and 1987, expectedly facilitating the favorable outcomes of cyclically adjusted primary surpluses of more than 4 percent in 1995-1997. These three examples also stress that I expect longer time perspectives to facilitate fiscal outcomes irrespective of the ideological orientation of the governing parties involved.

Are there alternative factors which condition the effectiveness of coalitions' cooperation outlooks to contain debt dynamics? First, since fiscal policy sometimes co-varies with electoral cycles (Nordhaus 1975) and even governments with long-term cooperation prospects face electoral uncertainties (Jacobs 2011; Lupia and Strøm 2008), election years should temporarily suspend debt stabilization efforts of governments seeking re-election. Second, if the assumption is valid that parties care about the costs of future debt (see above), the incentives that cooperation involves long-sighted fiscal policy-making should be stronger when the government faces greater fiscal pressure. Third, even when governing parties agree on debtstabilizing policies, the effectiveness of fiscal outcomes may depend on the degree of centralization in budgetary institutions - especially in the delegation of fiscal authority to strong finance ministers (Hallerberg et al. 2009; Hallerberg and von Hagen 1999). This leads to three sub-hypotheses:

H2: The effects of prospective cooperation on debt changes are strongest in non-election years. 
H3: The effects of prospective cooperation on debt changes are strongest under high fiscal pressure.

H4: The effects of prospective cooperation on debt changes are strongest under high fiscal delegation.

Whilst these factors are expected to moderate the strength of the effect of prospective cooperation, they are not necessary conditions determining whether cooperation effects take place at all. In other words, one should find evidence for lower debt growth of coalitions with long time horizons even during election years, under low fiscal pressure, and under low centralization of budgetary institutions.

\section{Data and operationalization}

The argument is put to an empirical test by comparing 36 post-industrial democracies: the 28 EU member states, in addition to OECD member states Australia, Canada, Iceland, Japan, New Zealand, Norway, Switzerland and the United States. The data set comprises more than 600 governments. Maximally, the observation period goes from 1962 to 2013, but starts only after the democratic transition of each country. Unless noted otherwise, all government data are from Armingeon et al. (2015b) and all political-economic control variables from Armingeon et al. (2015c). Tables A1 and A2 in the online appendix provide details on the operationalization and descriptive statistics of all variables.

\section{Debt change}

Following several studies, the dependent variable is the annual change (first differences) in gross general government debt ratios in percentage of GDP (Bäck and Lindvall 2015; Franzese 2002). Debt data are based on OECD Economic Outlook and Eurostat sources, but time series are extended through backward extrapolation, mostly in the 1960s and 1970s, using data from the IMF (Abbas et al. 2010) and Reinhart and Rogoff (2009) (for details see Armingeon et al. 2015c). Using non-extrapolated data yields substantially identical results (see the section below on robustness tests). Debt ratios correlate with measures of budget deficits, but may be less prone to "creative accounting" of governments (Alt et al. 2012). Since growth and interest payments also influence debt trajectories, debt changes encompass the entirety of public finance development both on the expenditure and revenue side. Nonetheless, my results are robust to alternative indicators, such as budget deficits or government expenditure. 


\section{Government form}

The differentiation between coalition/multi-party governments and one-party governments is the first important independent variable following from the theoretical argument (coalitions coded 1; one-party governments coded 0 ).

\section{Prospective cooperation}

“Prospective cooperation” encompasses current governing parties' chance for a future participation in government in the same constellation. This measure is based on the idea of familiarity through shared past governing experience, which should enable governments to take a more credible long-term perspective on debt dynamics. It is detrimental for prospective cooperation if current coalition partners frequently governed with other parties or governed alone in the past. Such dissenting behavior reduces coalition partners' familiarity and mutual trust (Tavits 2008); there is no stable foundation for long-term cooperation based on successful past collaborative experiences, thus damaging the credibility of fiscal policy agreements.

The measure for prospective cooperation is constructed retrospectively and oriented towards past cooperation, following Bäck and Lindvall (2015) and similar measures by Persson and Tabellini (2009) and Martin and Stevenson (2010). It is assumed that each governing party judges the chances for prospective cooperation on account of its past cooperation experiences with other governing parties. Since familiarity is a dynamic concept that is developed over time, all cooperation experiences since 1960 are taken into account for all governing parties in the data set.

However, there are reasons to "discount” past events because coalitions have to compare present benefits and future benefits facing uncertainty about the future (Lupia and Strøm 2008). For governments with higher discount rates, the potential for prospective cooperation should depend more strongly on recent government constellations than on patterns from decades ago. The functional form of how past government events have to be discounted is unclear a priori, though. Measuring democratic capital, Persson and Tabellini $(2009,101)$ are "agnostic" about the functional form and assume that democratic capital accumulates relatively slowly in democratic years but collapses rapidly if a regime becomes authoritarian. Past events are discounted with a geometrical depreciation function in this specification. For prospective cooperation, a similar intuition seems reasonable, in that familiarity is inherently developed over a longer time period than it can be disestablished. Bäck and Lindvall (2015) follow the logic of Persson and Tabellini (2009) and set the depreciation rate at 0.95. This leads to a weight of $0.95^{0}=1$ for an event one year ago, $0.95^{1}=0.95$ two years ago, $0.95^{2}=0.903$ three years 
ago, $0.95^{3}=0.857$ four years ago, etc. Events about fifteen years ago carry half the weight of past year's events. The closer the depreciation rate is to 1 , the more all past events are weighted equally. The closer it is to 0 , the more weight recent events carry.

Martin and Stevenson (2010) also use discount rates for their measure of familiarity. They argue that familiarity provides insider information about coalition partners, but that this process depends on the collaboration of party leaders. Because they estimate average durations of party leadership in Western Europe at about eight years, cooperation events more than eight years ago are "almost completely discounted” (Martin and Stevenson 2010, 510). This would imply a depreciation rate of about 0.7 or 0.8 . But, this may be too restrictive since depreciation rate events three years ago weigh only about half $\left(0.7^{2}=0.49\right)$. Rather, a higher rate seems appropriate. In this article, I will mainly apply a depreciation rate of 0.95 - yet rerun all analyses for twenty different depreciation rates between 0.80 and 0.99 (online appendix).

The actual calculation of the indicator is leaned on Bäck and Lindvall (2015) and correlates strongly with their measure $(\mathrm{r}=0.84, \mathrm{~N}=1,011) .{ }^{4}$ In an initial step, a measure for prospective cooperation is developed for each individual governing party $j$ in country $i$ in the year $t$ :

$$
\text { Prospective cooperation }_{i, j, t}=(1-\delta) \sum_{\tau=1}^{\tau=t-t_{0}} \alpha_{i, j, t-\tau} * \delta^{\tau-1} \text {, }
$$

where $\delta$ is a depreciation rate ( $\delta=0.95$ in the main analyses). $\tau$ denotes all past observations that are taken into account for the calculation the indicator, starting with $t-1$ and ending with the first time point in the data set (1960 at the earliest). By multiplication with $(1-\delta)$, the sum of all past observations of prospective cooperation is normalized to an interval between 0 and 1. The degree of past cooperation is captured by $\alpha_{i, j, t-\tau}$. If a current governing party (year $t$ ) has previously participated in government in year $t-\tau$, there are three possibilities:

- It gets a maximum value of $\alpha=1$ if it was in a coalition with the exact same partners in the past year $t-\tau$.

- It gets a minimum value of $\alpha=0$ if it was in a coalition with entirely different partners in the past year $t-\tau$. Note that this also includes cases where a party has governed alone in the past, but now forms part of a coalition.

- It gets values between 0 and 1 if only a share of the current coalition partners have cooperated in government in the past year $t-\tau$. The value is then the share of current governing parties that have cooperated with party $j$ in that year. ${ }^{5}$ 
For single-party governments and new governing parties, different logics apply as a comparison of their current and past cooperation status is not straightforward.

- Single-party governments: According to the argument, the policy-making outcomes of coalitions' past cooperation patterns need to be compared to the outcomes of parties governing alone, i.e. not cooperating with other parties. Foremost, therefore, the effect of single-party governments versus coalitions is captured by a separate dummy variable. For the cooperation variable, single-party governments are simply assigned a constant value (whose exact level is technically irrelevant, due to the additional dummy variable). In accordance with the view that parties can be seen as durable, stable coalitions of societal interests (Aldrich 2011) with similar incentives like durable coalition governments to internalize fiscal preferences, parties governing alone in a given year get a maximum value of $\alpha=1$.

- New governing parties: Although they have not established any familiarity with other governing parties in the past, I assign new parties in government a maximum value of $\alpha=1$. The reason is that otherwise the measure would "punish" a new party for not having participated in previous governments, even though it might be willing to collaborate and compromise in office. Its coalition partners, however, have a relative lack of familiarity with the new party, which reflects in a lower cooperation outlook for established parties. This is a compromise between the view that new parties should have low cooperation prospects due to their lack of familiarity with the established parties, and the view that new parties should have high cooperation prospects because they have never "betrayed" the established parties.

These cases reveal that governing parties within one coalition may have different individual values of prospective cooperation. I argue that the foundation for durable cooperation depends on the elaborated amount of familiarity among all coalition partners, since, "no coalition government is stronger than its weakest link” (Bäck and Lindvall 2015, 58). The effects of familiarity on future cooperation prospects therefore prevail for the coalition as a whole; otherwise, some parties could impede debt stabilization agreements, lacking long-term cooperation perspectives. In a second step, the potential for prospective cooperation for a government in country $i$ in the year $t$ is thus the lowest value of prospective cooperation of any current governing party:

$$
\text { Prospective cooperation }_{i, t}=\min \left(\text { Prospective cooperation }_{i, j, t}\right)
$$




\section{[FIGURE 1 ABOUT HERE]}

Figure 1 illustrates the development of prospective cooperation for each country, while also displaying the dynamics of debt ratios. In countries continuously ruled by one-party governments or unchanged coalitions, prospective cooperation always reaches the maximum value of 1 (Australia, Canada, Cyprus, Malta, Spain and USA). ${ }^{6}$ In the rest of the 36 democracies, prospective cooperation varies over time. For example, in the United Kingdom the conservative-liberal coalition government formed in 2010 has a lower potential for prospective cooperation because the Conservatives had governed alone since 1960, and the Liberals have no familiarity through shared governing experience with the Conservatives. Indeed, the Conservatives went back to governing alone after the elections in 2015.

In Switzerland, another system of generally stable coalition patterns, with the same parties forming the government between 1959 and 2011, there is a surprising dip in 1995. This is because in our data source, the SVP was recoded to a right-populist party since 1995, and in effect became a "new" party (in an ideological sense). Thus, the expectations for the "old" parties for long-term cooperation with the new party are reduced. However, the indicator drops only moderately because three of the four parties can still count on a high amount of familiarity.

Austria is an illustrative case to see the intuition of the indicator. Until 1982, after a long series of grand coalitions between 1947 and 1966, the SPÖ and ÖVP governed alone. In 1983, prospective cooperation decreases below 0.5 after the SPÖ for the first time entered a coalition with the FPÖ. The socialists thus have a high potential for "betrayal" against its partner because they had governed alone or with the ÖVP for such a long time. During the four-year government term, prospective cooperation slowly increases again. But it slightly decreases again in 1987 with the next grand coalition between SPÖ and ÖVP because the Social Democrats now have a betrayal potential against the Christian Democrats too. Until 2000, prospective cooperation steadily increases under consecutive grand coalitions. It then falls again with the first coalition between ÖVP and FPÖ in 2000.

Japan is another demonstrative example. Until 1983, the Liberal Democrats governed alone. Between 1983 and 1986, and between 1994 and 2009, however, they had a series of small coalition partners. These have no familiarity because of the long-standing hegemony of the LDP and could not anticipate being a long-term part of a coalition government. Finally, the new accession countries of the EU in Central and Eastern Europe start from comparably high levels of prospective cooperation because their party systems are dominated by new parties 
(Powell and Tucker 2014). However, there are also clear downward trends in countries like Estonia, Latvia or Slovenia because of unstable coalition patterns in the 2000s. Such downward trends, as well as increasing volatility over time, are observable on average over all countries. This can possibly be explained by party system changes, but in any case, the cross-national variation remains considerable. $^{7}$

Looking at bivariate associations reveals negative but rather weak correlations between country-level averages of prospective cooperation and debt changes: $r=-0.07(\mathrm{~N}=36, \mathrm{p}=0.69)$ for all countries and $\mathrm{r}=-0.17(\mathrm{~N}=30, \mathrm{p}=0.38)$ excluding countries with permanent maximum values of prospective cooperation due to one-party governments. Correlation coefficients within countries are negative in 21 countries (significant on the 90\%-level in Belgium, Croatia, Estonia, France, Greece, Iceland, Japan, Portugal, Romania, Slovenia, Sweden and UK) and insignificantly positive in 9 countries ( $\mathrm{p}>0.1$ in all countries). Average debt changes confirm the theoretical expectations. One-party governments (average annual debt change $0.85 \%$ of GDP, N=532) and coalition governments with high values for prospective cooperation (debt change $0.80 \%$ of GDP, $\mathrm{N}=412$, prospective cooperation $>0.78$ ) both have substantially lower debt increases than coalitions with low values for prospective cooperation (debt change 1.80\% of GDP, $\mathrm{N}=418$ ).

\section{Control variables}

These bivariate correlations should be scrutinized in a multivariate model controlling for alternative influences on debt changes. The variables presented here allow a replication of the models in Bäck and Lindvall (2015). Their models in turn are based on the comprehensive empirical study by Franzese (2002, chapter 3). Control variables are from Armingeon et al. (2015c) and are described in detail in the online appendix. First, a number of economic control variables are introduced. The lagged values of debt changes and levels control for persistence of debt trajectories (see also a statistical motivation below). Also, higher debt growth should be immediately caused by higher unemployment levels and changes, lower GDP growth. Fiscal pressure, which hypothesis 3 expects to increase the effects of prospective cooperation, is operationalized as the leverage of GDP growth minus inflation minus nominal interest rates on lagged debt levels. Openness of the economy is not included in the main models as it proved insignificant.

Second, election years (binary indicator, $1=$ election year) should temporarily lower the effects of prospective cooperation, according to hypothesis 2. Third, to disentangle cooperation effects from government stability (Bejar et al. 2011), I include a measure for government 
duration based on the average duration of past government in days (applying a depreciation rate of 0.95)

Fourth, the cabinet share of left-wing parties is included as a control variable. The expected effects are somewhat ambiguous and may depend on macroeconomic conditions (Cusack 1999). Fifth, Edin and Ohlsson (1991) associate minority governments (1=minority in parliament) with higher deficits, but this has been contested (de Haan and Sturm 1997). Sixth, according to hypothesis 4, the impact of prospective cooperation may be conditional on sufficiently centralized budget institutions under the control of strong finance ministers (Hallerberg and von Hagen 1999). Thus, I include the "delegation index" by Hallerberg et al. $(2009,74)$ in some models. Data are available for 15 European countries and three time points only. I assign the value from 1991 backwards until 1960 and the value from 2000/2004 until 2012. Values between 1991 and 2000/2004 are linearly interpolated.

Finally, constitutional veto players need to be taken into account (Tsebelis 2002). I include indices for presidentialism ( $0=$ parliamentarism, 1/2/3=semi-presidentialism/hybrid systems, 4=presidentialism), federalism ( 0 =no, $1=$ =weak, $2=$ strong) and bicameralism (1=unicameralism, 2=weak bicameralism, 3=medium-strength bicameralism, 4=strong bicameralism).

\section{Method}

Standard political economy analyses often utilize pooled time-series cross-section regression methods (TSCS) using annual data. In this article, I use two approaches to study the association between governments' prospective cooperation and changes in debt ratios. First, within the TSCS-framework, “autoregressive distributed lag” models are applied which enable to discern short- and long-run relations. Second, I use cabinets as the unit of observation instead of country-years to avoid some pitfalls of standard TSCS-analysis.

\section{TSCS-analysis}

Autoregressive distributed lag (ADL) models enable one to identify the temporal impacts of governments' cooperation patterns. An ADL model is a "general model" in the sense that it makes no restrictive a priori assumptions about the dynamic associations between $\mathrm{X}$ - and $\mathrm{Y}$ variables (Beck and Katz 2011; De Boef and Keele 2008). The model is specified as follows:

$$
\Delta \text { DebtRatio }_{t}=\alpha_{0}+\alpha_{1} \Delta \text { DebtRatio }_{t-1}+\beta_{0} \boldsymbol{X}_{t}+\beta_{1} \boldsymbol{X}_{t-1}+\varepsilon_{t},
$$


where $\Delta$ DebtRatio is the annual change of general government debt in percentage of GDP and $\boldsymbol{X}$ is a vector of independent variables. $\beta_{0}$ estimates the immediate short-term effect, $\beta_{1}$ the effect of previous levels of $\boldsymbol{X}$ on debt changes. Including the lagged dependent variable $\alpha_{1}$

allows the calculation of long-run multipliers LRM $=\frac{\beta_{0}+\beta_{1}}{1-\alpha_{1}}$ which estimate the total long-run effect of an impact variable $\boldsymbol{X}$. $\varepsilon_{t}$ is an idiosyncratic error term.

The estimation of the ADL with ordinary least squares regression depends upon four assumptions which tests show to be consistent. First, throughout the whole sample, the dependent variable seems to be stationary and not containing unit roots. ${ }^{8}$ Second, Lagrange multiplier tests find no significant serial correlation among the residuals. ${ }^{9}$ This avoids endogeneity bias risks by introducing the lagged dependent variable (Keele and Kelly 2006). Third, spatial correlation among the error terms and panel heteroscedasticity ${ }^{10}$ require the use of “panel-corrected” standard errors (Beck and Katz 1995). Fourth, tests hint that the data do not suffer from unobserved heterogeneity between countries. ${ }^{11}$ Therefore, no country fixed effects need to be included (the results explaining variation within coalition governments remain robust in fixed-effects models, however). To control for common exogenous shocks and time trends, I include a year counter, and its squared and cubic transformation. Results are substantially identical using year fixed effects.

\section{Government-centered analysis}

TSCS-data have a number of disadvantages. Their focus on annual short-term changes ignores that governing occurs with implementation lags. Moreover, government output is to some degree driven by electoral cycles, which naturally includes governmental changes in the middle of the calendar year. An alternative to TSCS-data is therefore to set the unit of observation at the cabinet level, so that each observation captures the relevant average characteristics of one government. $^{12}$ Because cabinet duration varies greatly, I control for the number of days governments were in office. Models are estimated with OLS regression and panel-corrected standard errors. The main advantage using this cabinet-centered data structure is a more realistic focus of the government as a main actor shaping policy (Boix 1997; Obinger et al. 2014).

\section{Results}

[TABLE 1 ABOUT HERE] 
The empirical evidence presented in this chapter is based firstly on ADL-models and then revisited with the government-centered data setting. The first model in Table 1, an economic baseline model, shows the expected debt increases when the economic situation deteriorates. Model 2 finds a significant positive association between coalitions and debt in the short-term, but no long-run relationship. ${ }^{13}$ As argued in this article, crucial variation seems to be located within coalition governments. Model 3, introducing the measure for prospective cooperation, finds a significant difference between coalitions with short and long time horizons. Coalitions with future cooperation prospects are associated with lower debt increases both in the short and the long run. In substantive terms, expected annual debt increases are about 1 percentage point lower, on average, if the value for prospective cooperation increases by one standard deviation (about 0.2 units). Moreover, coalitions with maximum cooperation prospects are now related to significantly lower debt changes in the long run compared to single-party governments (see below).

While Model 4 completes the set of political and institutional control variables, the strong effects of prospective cooperation remain unaltered. Again, prospective cooperation has a substantial effect. In a hypothetical example, if the value for prospective cooperation decreased from 1 to 0.5 , debt would grow from 80 percent to 128 percent of GDP within 20 years, all else equal. ${ }^{14}$ Impulse response functions (IRF) from Model 4 show that the effect of prospective cooperation is -2.68 in the first year, -1.66 in the second year, -0.34 in the third year, and 0.07 in the fourth year (see the IRFs in Figure A4 in the online appendix).

The coefficient for coalition governments - the difference between coalition and singleparty governments - needs to be interpreted conditionally on values of prospective cooperation since one-party governments always take the maximum value of $1 .{ }^{15}$ Figure 2 shows the marginal effects of coalition governments. In the short-run, debt growth under coalitions and one-party governments is not significantly different. In the long-run, however, coalitions with prospective cooperation values over 0.78 have significantly lower debt increases compared to one-party governments (on the 95\%-level). These comprise more than 45 percent of all coalition governments. On the other hand, coalitions with a prospective cooperation score below 0.48 have significantly higher debt increases than single-party governments. These findings indicate - consistent with the main hypothesis - that the higher number of parties in coalitions does not directly lead to common pool problems, but, that coalitions with long time horizons can even be superior to single-party governments based on their ability to generate broad political support for controversial reform policies. ${ }^{16}$ 


\section{[FIGURE 2 ABOUT HERE]}

The control variables show that - apart from a short-term impact - government duration is not significantly associated with lower debt increases. Federalism has the expected negative effect, while presidentialism and bicameralism show no clear, robust effects. Minority and left-wing governments are related to lower debt increases (cf. Alesina and Perotti 1995).

Table 2 (regressions) and Table 3 (marginal effects) account for the possibility that the effect of prospective cooperation is conditioned by other explanatory factors. Model 5 shows that the effect of prospective cooperation is weakened in election years, but stronger in nonelection years, as expected in hypothesis 2 following the political business cycle logic. Model 6 finds that prospective cooperation is most clearly related to lower debt growth when fiscal pressure is high. This provides some evidence for the assumption in the theoretical argument in hypothesis 3 that coalitions with a longer time horizon effectively care more about future debt costs. When the fiscal situation is comfortable, cooperation effects are weaker - presumably because governments can afford fiscal expansion without endangering long-run debt sustainability. Finally, Model 7 indicates that the impact of prospective cooperation is stronger with centralized budget process institutions and strong finance ministers (high delegation index, hypothesis 4). However, the data for delegation are suboptimal and the interaction between delegation and prospective cooperation is only narrowly significant on the $90 \%$-level, which indicates that this finding should be tested more carefully in future research. ${ }^{17}$

The results presented so far are robust to a variety of tests. First, revisiting measurement assumptions of prospective cooperation, any depreciation rate between $\delta=0.8$ and $\delta=0.99$ yields substantially identical long-run effects (see Figures A1 and A2 in the online appendix). Second, the results are robust to alternative specifications of the dependent variable, such as nonextrapolated debt changes, total government expenditure or government deficits. Third, findings remain unchanged with the inclusion of other control variables (a dummy variable for governments consisting entirely of new parties; number of new parties in governments; total ministers as a proxy for the number of spending ministers; formal budgetary rules; openness of the economy; number of parties in government; effective number of parties in parliament; government support in parliament; or dummy variables for the Eurozone, caretaker or technocratic cabinets, oversized or minimal winning coalitions, and proportional representation electoral systems). Fourth, the results are robust to several alternative methodical choices. ${ }^{18}$ With country fixed effects, the difference between single-party and coalition governments is not significant (Model A1 in the online appendix), but since these are within-group effects, all 
countries with constant single-party, or more importantly, constant coalition government, are disregarded. Fifth, there is only limited risk of endogeneity and reverse causality - i.e. debt shocks disarranging historical coalition patterns - since debt changes, especially in the longrun, are not significantly leading to changes in prospective cooperation (Models A4 to A8 in the online appendix).A substantive issue concerns the assumption of parameter heterogeneity in pooled time-series analysis (Plümper et al. 2005). I construct five period dummies in order to test how the effect of prospective cooperation varies over time: a "Bretton-Woods" period (1962-1972); a “post-oil-shock” period (1973-1989); a “Maastricht” period (1990-1998) capturing increased volatility in the 1990s partly associated with the convergence efforts of the Maastricht treaty in Europe; a "Euro" period (1999-2007) witnessing the introduction of the common currency in the Eurozone; and a “Great Recession” period (2008-2013) capturing the economic crisis. These period dummies are interacted with the prospective cooperation variable. The regression coefficients are then standardized in order to compare the relative magnitude of the effects.

\section{[TABLE 4 ABOUT HERE]}

Table 4 shows that the substantive debt impact of prospective cooperation is greatest until the 1980s, possibly because influencing the economy through Keynesian demand management was still feasible. The effect has been attenuated in the 1990s and 2000s. During the Great Recession since 2008, the magnitude of the effect is relatively small, which comes as no surprise since governments of all forms increasingly relied on austerity policies (Armingeon and Baccaro 2012).

\section{[TABLE 5 ABOUT HERE]}

Finally, Table 5 shows the results of the government-centered regression analysis which overcomes some drawbacks of TSCS-data. Model 8 is a replication of Model 4, while Model 9 excludes the lagged dependent variable which theoretically makes less sense because cabinets should be more independent units of observation than country-years. The findings corroborate the effect of coalitions' prospective cooperation: On average, throughout entire administrations, coalitions with a prospective cooperation score of 1 are associated with debt increases 2.1 percentage points lower than coalitions with scores of 0.5 (Model 9). But the results find no significant difference between single-party governments and coalitions with 
high cooperation prospects. As argued in the theoretical section, broad coalitions are potentially better suited to implement debt stabilization policies with their ability to spread blame and policy accountability across several actors - yet they also need more time to agree on policy change. This implies that the average values used in this government-centered analysis may cloud these policy-making differences between coalitions and single-party governments. Indeed, when controlling for the variance of cabinets' debt changes (expectedly higher under coalition governments) in Model 10, coalition governments with high cooperation outlooks are associated with significantly lower debt accumulation rates than one-party governments. These results remain robust when short-term governments, which were in office less than six months, are excluded.

\section{Conclusion}

Do durable cooperation patterns among governing parties help to keep debt dynamics in check? The evidence presented in this article, based on a comparison of 36 democracies over the time period from (up to) 1962 to 2013, shows that coalitions with high chances for "prospective cooperation" are indeed associated with lower debt increases - compared to both coalitions of parties less familiar through past shared-governing experience and to single-party governments.

The assumptions behind the theoretical argument are that the familiarity gained from governing together increases the chance of future cooperation (Franklin and Mackie 1983; Martin and Stevenson 2001, 2010) and that those coalitions with governing prospects care about the future costs of debt. Under these conditions, for which I provide empirical support, incentives for coalition governments to externalize the future costs of debt are reduced significantly. Echoing a recent argument put forward by Bäck and Lindvall (2015), this challenges standard fragmentation and veto-player approaches, where long-term considerations by political actors are often absent (Bawn and Rosenbluth 2006; Roubini and Sachs 1989; Tsebelis 2002). This is problematic since long-lasting cooperation might be a strategy to overcome some of the opportunity problems arising from intertemporal insecurity over future events (Lupia and Strøm 2008).

Moreover, and going beyond Bäck and Lindvall (2015), I found some evidence that fiscal policy-making is not reducible merely to veto actor or common pool resource problems. The literature on consensus government highlights that the assumptions from veto player theories are often insufficient to incorporate issues of electoral support for controversial policies. In this view, broad and durable coalitions indeed have advantages over one-party governments to negotiate reform packages with a fairly balanced distribution of the burden and gains across 
several societal groups and to share the blame for unpopular policy measures (Katzenstein 1985; Lijphart 2012).

Does cooperation stability have the same effects for ideologically broad coalitions (such as the grand coalitions in Austria, Germany, or Switzerland) as for ideologically narrower, but durable, coalitions (for example, the Swedish center-right alliance)? How do the distinct veto actor constellations between one-party and coalition governments affect their time requirements and timing to agree on policy change? Finally, do budgetary institutions, such as the delegation of fiscal authority to the finance minister, interfere with coalitions' striving for fiscal policy agreements? These issues, not yet fully answered in this analysis, merit further study to better understand economic policy-making differences between one-party and multiparty types of government. The evidence, though, is compelling that long-sighted coalition behavior pays off to reach particular policy goals.

\section{Acknowledgements}

For valuable comments and suggestions, the author would like to thank Klaus Armingeon, Sarah Engler, Drew Sampson, Isabelle Stadelmann-Steffen, the participants of the "Social Policy and Political Economy" workshop at the Annual Congress of the Swiss Political Science Association in Basel in January 2016, as well as the coeditor of Journal of Public Policy, Fabrizio Gilardi, and two anonymous reviewers. Replication materials are available at http://dx.doi.org/10.7910/DVN/KKQOAS.

\section{References}

Abbas, S. M. A., N. Belhocine, A. A. ElGanainy and M. A. Horton (2010) A Historical Public Debt Database. IMF Working Paper 10/245.

Aldrich, J. H. (2011) Why Parties? A Second Look. Chicago: University of Chicago Press. Alesina, A. and A. Drazen (1991) Why are Stabilizations Delayed? The American Economic Review 81: 1170-88.

Alesina, A. and R. Perotti (1995) The Political Economy of Budget Deficits. Staff Papers (International Monetary Fund) 42: 1-31.

Alexiadou, D. (2013) In Search of Successful Reform: The Politics of Opposition and Consensus in OECD Parliamentary Democracies. West European Politics 36: 704-25.

Alt, J., D. Dreyer Lassen and J. Wehner (2012) Moral Hazard in an Economic Union: Politics, Economics, and Fiscal Gimmickry in Europe. LSE Political Science and Political Economy Working Paper 5/2012.

Armingeon, K. and L. Baccaro (2012) Political Economy of the Sovereign Debt Crisis: The Limits of Internal Devaluation. Industrial Law Journal 41: 254-75. 
Armingeon, K., K. Guthmann and D. Weisstanner (2014) Politische Voraussetzungen von Austeritätspolitik: Ein internationaler Vergleich von 17 etablierten Demokratien zwischen 1978 und 2009. Zeitschrift für Staats- und Europawissenschaften 12: 242-71. (2015a) Choosing the path of austerity: how parties and policy coalitions influence welfare state retrenchment in periods of fiscal consolidation. West European Politics online first: $1-20$.

Armingeon, K., C. Isler, L. Knöpfel and D. Weisstanner (2015b) Supplement to the Comparative Political Data Set - Government Composition 1960-2013. Bern: Institute of Political Science, University of Berne.

Armingeon, K., C. Isler, L. Knöpfel, D. Weisstanner and S. Engler (2015c) Comparative Political Data Set 1960-2013. Bern: Institute of Political Science, University of Berne.

Bäck, H. and P. Dumont (2007) Combining large-n and small-n strategies: The way forward in coalition research. West European Politics 30: 467-501.

Bäck, H. and J. Lindvall (2015) Commitment Problems in Coalitions: A New Look at the Fiscal Policies Of Multiparty Governments. Political Science Research and Methods 3: 53-72.

Bawn, K. and F. Rosenbluth (2006) Short versus Long Coalitions: Electoral Accountability and the Size of the Public Sector. American Journal of Political Science 50: 251-65.

Beck, N. and J. N. Katz (1995) What To Do (and Not to Do) with Time-Series Cross-Section Data. American Political Science Review 89: 634-47.

(1996) Nuisance vs. Substance: Specifying and Estimating Time-Series-Cross-Section Models. Political Analysis 6: 1-36.

(2011) Modeling Dynamics in Time-Series-Cross-Section Political Economy Data. Annual Review of Political Science 14: 331-52.

Bejar, S., B. Mukherjee and W. H. Moore (2011) Time horizons matter: the hazard rate of coalition governments and the size of government. Economics of Governance 12: 20135.

Boix, C. (1997) Privatizing the Public Business Sector in the Eighties: Economic Performance, Partisan Responses and Divided Governments. British Journal of Political Science 27: 473-96.

Bojar, A. (2015) Intra-governmental bargaining and political budget cycles in the European Union. European Union Politics 16: 90-115.

Cusack, T. R. (1999) Partisan Politics and Fiscal Policy. Comparative Political Studies 32: 464-86.

De Boef, S. and L. Keele (2008) Taking Time Seriously. American Journal of Political Science 52: 184-200.

de Haan, J. and J.-E. Sturm (1997) Political and economic determinants of OECD budget deficits and government expenditures: A reinvestigation. European Journal of Political Economy 13: 739-50.

Edin, P.-A. and H. Ohlsson (1991) Political determinants of budget deficits: Coalition effects versus minority effects. European Economic Review 35: 1597-603.

Franklin, M. N. and T. T. Mackie (1983) Familiarity and Inertia in the Formation of Governing Coalitions in Parliamentary Democracies. British Journal of Political Science 13: 275-98.

Franzese, R. J., Jr. (2002) Macroeconomic Policies of Developed Democracies. Cambridge: Cambridge University Press.

Grilli, V., D. Masciandaro and G. Tabellini (1991) Political and Monetary Institutions and Public Financial Policies in the Industrial Countries. Economic Policy 6: 342-92.

Hallerberg, M. and J. von Hagen (1999) Electoral Institutions, Cabinet Negotiations, and Budget Deficits in the European Union. In Fiscal Institutions and Fiscal Performance, eds. J. M. Poterba and J. von Hagen. Chicago: University of Chicago Press. 209-32. 
Hallerberg, M., R. R. Strauch and J. von Hagen (2009) Fiscal Governance in Europe. New York: Cambridge University Press.

Hübscher, E. (2015) The politics of fiscal consolidation revisited. Journal of Public Policy FirstView: 1-29.

Jacobs, A. M. (2011) Governing for the Long Term: Democracy and the Politics of Investment. New York: Cambridge University Press.

Katzenstein, P. J. (1985) Small States in World Markets. Industrial Policy in Europe. Ithaca/London: Cornell University Press.

Keele, L. and N. J. Kelly (2006) Dynamic Models for Dynamic Theories: The Ins and Outs of Lagged Dependent Variables. Political Analysis 14: 186-205.

König, P. D. and G. Wenzelburger (2014) Toward a Theory of Political Strategy in Policy Analysis. Politics \& Policy 42: 400-30.

Kreps, D. M. (1990) Corporate culture and economic theory. In Perspectives on Positive Political Economy, eds. J. E. Alt and K. A. Shepsle. Cambridge: Cambridge University Press. 90-143.

Kydland, F. E. and E. C. Prescott (1977) Rules Rather than Discretion: The Inconsistency of Optimal Plans. Journal of Political Economy 85: 473-91.

Lijphart, A. (2012) Patterns of Democracy: Government Forms and Performance in ThirtySix Countries. 2 ed. New Haven/London: Yale University Press.

Linz, J. J. (1998) Democracy's Time Constraints. International Political Science Review 19: 19-37.

Luebbert, G. M. (1984) A Theory of Government Formation. Comparative Political Studies 17: 229-64.

Lupia, A. and K. Strøm (2008) Bargaining, Transaction Costs, and Coalition Governance. In Cabinets and Coalition Bargaining. The Democratic Life Cycle in Western Europe, eds. K. Strøm, W. C. Müller and T. Bergmann. Oxford: Oxford University Press. 51-83.

Majone, G. (1996) Temporal Consistency and Policy Credibility: Why Democracies Need Non-Majoritarian Institutions. ed. E. U. I. W. P. R. N. 96/57.

Martin, L. W. and R. T. Stevenson (2001) Government Formation in Parliamentary Democracies. American Journal of Political Science 45: 33-50. (2010) The Conditional Impact of Incumbency on Government Formation. The American Political Science Review 104: 503-18.

Müller, W. C. and K. Strøm, eds. (1999) Policy, Office, or Votes? How Political Parties in Western Europe Make Hard Decisions. Cambridge: Cambridge University Press.

Nordhaus, W. D. (1975) The Political Business Cycle. The Review of Economic Studies 42: 169-90.

Obinger, H., C. Schmitt and R. Zohlnhöfer (2014) Partisan Politics and Privatization in OECD Countries. Comparative Political Studies 47: 1294-323.

Persson, T., G. Roland and G. Tabellini (2007) Electoral rules and government spending in parliamentary democracies. Quarterly Journal of Political Science 2: 155-88.

Persson, T. and G. Tabellini (2009) Democratic Capital: The Nexus of Political and Economic Change. American Economic Journal: Macroeconomics 1: 88-126.

Plümper, T., V. E. Troeger and P. Manow (2005) Panel data analysis in comparative politics: Linking method to theory. European Journal of Political Research 44: 327-54.

Powell, E. N. and J. A. Tucker (2014) Revisiting Electoral Volatility in Post-Communist Countries: New Data, New Results and New Approaches. British Journal of Political Science 44: 123-47.

Powell, G. B., Jr. and G. D. Whitten (1993) A Cross-National Analysis of Economic Voting: Taking Account of the Political Context. American Journal of Political Science 37: 391-414. 
Reinhart, C. M. and K. S. Rogoff (2009) This Time Is Different. Eight Centuries of Financial Folly. Princeton: Princeton University Press.

Roubini, N. and J. D. Sachs (1989) Political and economic determinants of budget deficits in the industrial democracies. European Economic Review 33: 903-33.

Sakamoto, T. (2001) Effects of Government Characteristics on Fiscal Deficits in 18 OECD Countries, 1961-1994. Comparative Political Studies 34: 527-54.

Schmid, J. (1990) Die CDU: Organisationsstrukturen, Politiken und Funktionsweisen einer Partei im Föderalismus. Opladen: Leske + Budrich.

Tavits, M. (2008) The Role of Parties' Past Behavior in Coalition Formation. The American Political Science Review 102: 495-507.

Tsebelis, G. (2002) Veto Players. How Political Institutions Work. Princeton: Princeton University Press.

von Hagen, J. and I. J. Harden (1995) Budget processes and commitment to fiscal discipline. European Economic Review 39: 771-79.

Warwick, P. V. (1996) Coalition Government Membership in West European Parliamentary Democracies. British Journal of Political Science 26: 471-99.

Weaver, R. K. (1986) The Politics of Blame Avoidance. Journal of Public Policy 6: 371-98.

Weingast, B. R., K. A. Shepsle and C. Johnsen (1981) The Political Economy of Benefits and Costs: A Neoclassical Approach to Distributive Politics. Journal of Political Economy 89: 642-64. 


\section{Figures and tables}
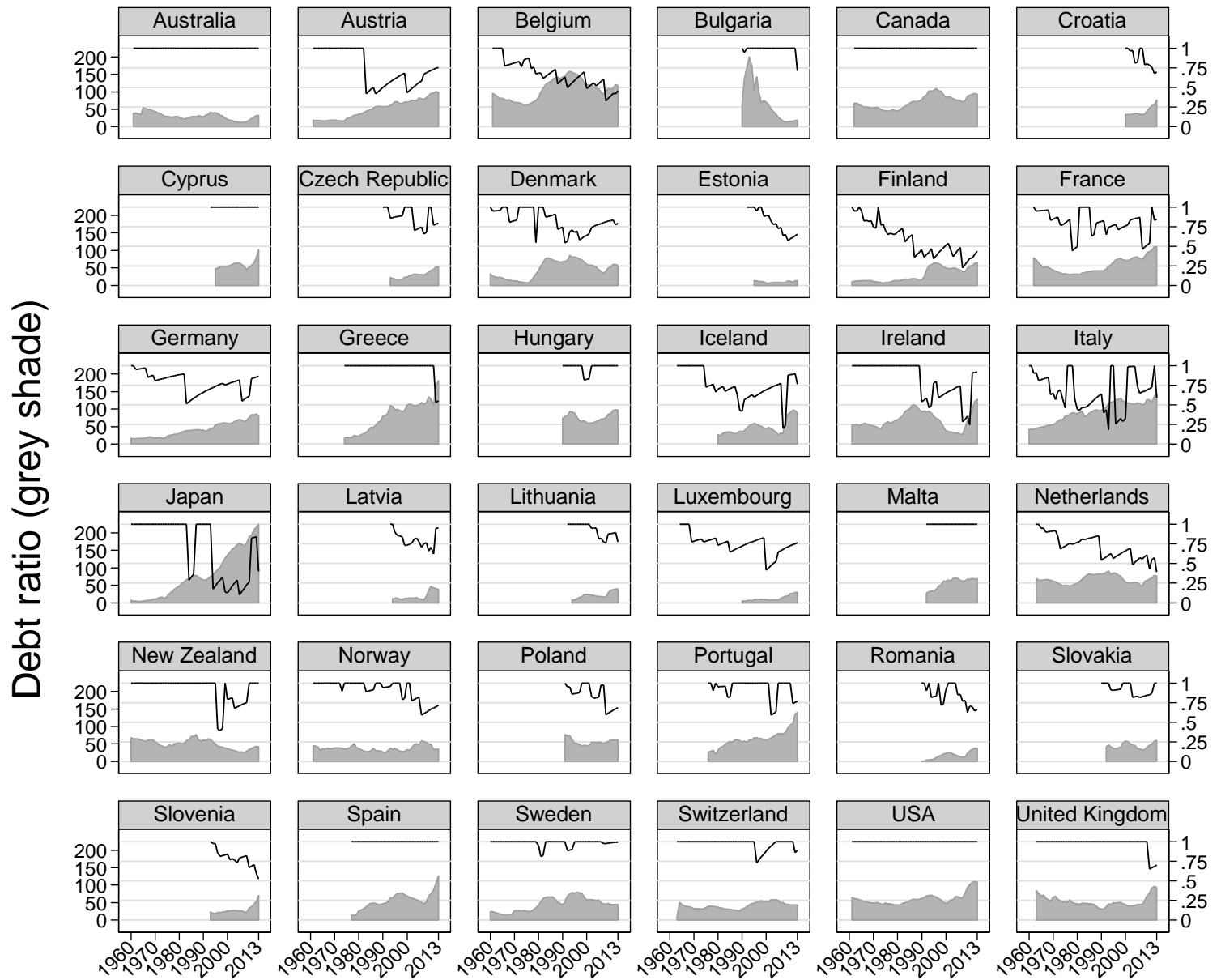

United Kingdom

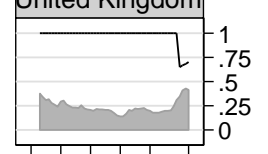

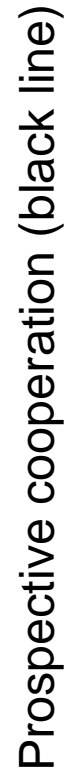

\section{Year}

Figure 1: Prospective cooperation and debt ratios, 1960-2013

Note: Debt ratio of Bulgaria in 1993 (292\%) reduced to 200\% for graphical reasons.

Source: Own calculations based on Armingeon et al. (2015b); Armingeon et al. (2015c). 

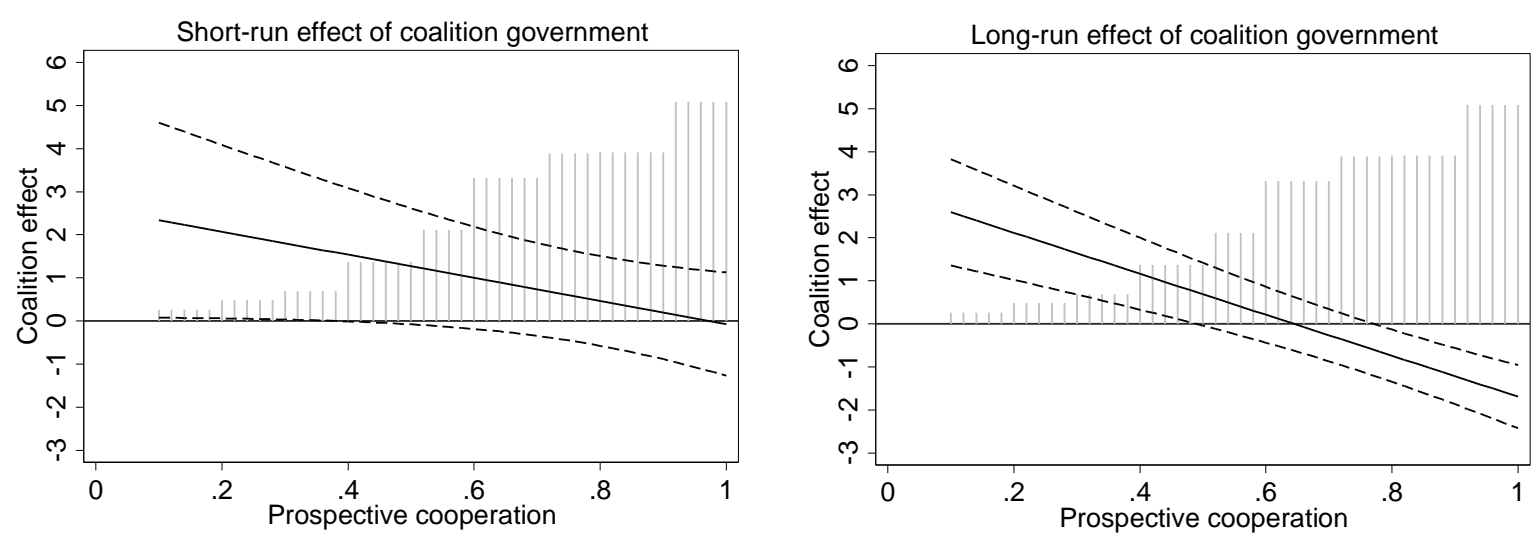

Figure 2: Group difference between coalition and single-party governments

Note: Dashed lines are 95\% confidence intervals. Vertical grey lines show distribution of prospective cooperation (coalition governments only). Based on Model 4. 
Table 1: ADL regressions of annual debt changes

\begin{tabular}{|c|c|c|c|c|c|c|c|c|}
\hline & Model 1 & & Model 2 & & Model 3 & & Model 4 & \\
\hline$\overline{\Delta \text { Debt ratio }}{ }_{\mathrm{t}-1}(\mathrm{LDV})$ & $0.213^{* * *}$ & $(0.046)$ & $0.216^{* * *}$ & $(0.046)$ & $0.211^{* * *}$ & $(0.045)$ & $0.203^{* * *}$ & $(0.045)$ \\
\hline Debt ratio $_{t-1}$ & $-0.013^{* *}$ & $(0.006)$ & $-0.012 * *$ & $(0.006)$ & $-0.018 * * *$ & $(0.006)$ & $-0.022 * * *$ & $(0.006)$ \\
\hline Real GDP growth $_{t}$ & $-0.295^{* * *}$ & $(0.082)$ & $-0.291 * * *$ & $(0.082)$ & $-0.291^{* * *}$ & $(0.081)$ & $-0.301 * * *$ & $(0.081)$ \\
\hline Unemployment $\mathrm{t}$ & $0.086^{* *}$ & $(0.038)$ & $0.084 * *$ & $(0.038)$ & $0.105^{* * *}$ & $(0.037)$ & $0.119 * * *$ & $(0.037)$ \\
\hline$\Delta$ Unemployment $_{\mathrm{t}}$ & $0.839 * * *$ & $(0.164)$ & $0.846^{* * *}$ & $(0.164)$ & $0.812^{* * *}$ & $(0.162)$ & $0.786^{* * *}$ & $(0.162)$ \\
\hline Fiscal pressure $_{t}$ & $0.004^{* * *}$ & $(0.001)$ & $0.004 * * *$ & $(0.001)$ & $0.004 * * *$ & $(0.001)$ & $0.004 * * *$ & $(0.001)$ \\
\hline Coalition government $t$ & & & $1.169^{* *}$ & $(0.519)$ & 0.416 & $(0.601)$ & -0.071 & $(0.611)$ \\
\hline Coalition government $t_{t-1}$ & & & $-1.104 * *$ & $(0.515)$ & $-1.303 * *$ & $(0.589)$ & $-1.277 * *$ & $(0.592)$ \\
\hline LRM Coalition government & & & 0.083 & $(0.247)$ & $-1.125 * * *$ & $(0.319)$ & $-1.691^{* * *}$ & $(0.374)$ \\
\hline Prospective cooperation $_{t}$ & & & & & $-3.041^{* *}$ & $(1.491)$ & $-2.679 *$ & $(1.474)$ \\
\hline Prospective cooperation $_{\mathrm{t}-1}$ & & & & & -0.726 & $(1.497)$ & -1.115 & $(1.472)$ \\
\hline LRM Prospective cooperation & & & & & $-4.775 * * *$ & $(0.826)$ & $-4.759 * * *$ & $(0.851)$ \\
\hline Election year $_{\mathrm{t}}$ & & & & & & & $0.585^{* *}$ & $(0.287)$ \\
\hline Election year $\mathrm{t}-1$ & & & & & & & $0.571^{* *}$ & $(0.279)$ \\
\hline LRM Election year & & & & & & & $1.450^{* * *}$ & $(0.486)$ \\
\hline Government duration $_{\mathrm{t}}$ & & & & & & & $-0.006^{*}$ & $(0.004)$ \\
\hline Government duration $_{\mathrm{t}-1}$ & & & & & & & $0.006^{*}$ & $(0.004)$ \\
\hline LRM Government duration & & & & & & & -0.000 & $(0.000)$ \\
\hline Minority government $_{\mathrm{t}}$ & & & & & & & $-0.547^{*}$ & $(0.285)$ \\
\hline Left cabinet share $_{t}$ & & & & & & & $-0.009 * *$ & $(0.003)$ \\
\hline Presidentialism $_{\mathrm{t}}$ & & & & & & & 0.021 & $(0.083)$ \\
\hline Federalism $_{\mathrm{t}}$ & & & & & & & $-0.521 * * *$ & $(0.140)$ \\
\hline Bicameralism $_{\mathrm{t}}$ & & & & & & & $0.305^{* *}$ & $(0.152)$ \\
\hline Time-trend & $0.440^{* *}$ & $(0.195)$ & $0.444^{* *}$ & $(0.195)$ & $0.413^{* *}$ & $(0.195)$ & 0.309 & $(0.194)$ \\
\hline Time-trend ${ }^{2}$ & $-0.018^{* *}$ & $(0.007)$ & $-0.019 * *$ & $(0.008)$ & $-0.018^{* *}$ & $(0.007)$ & $-0.014^{*}$ & $(0.007)$ \\
\hline Time-trend $^{3}$ & $0.000^{* * *}$ & $(0.000)$ & $0.000^{* * *}$ & $(0.000)$ & $0.000^{* * *}$ & $(0.000)$ & $0.000^{* *}$ & $(0.000)$ \\
\hline Constant & -1.108 & (1.507) & -1.196 & (1.519) & $3.296 *$ & $(1.841)$ & $4.421^{* *}$ & (1.851) \\
\hline$\overline{R^{2}}$ & 0.37 & & 0.37 & & 0.38 & & 0.39 & \\
\hline$N$ & 1,210 & & 1,210 & & 1,210 & & 1,210 & \\
\hline
\end{tabular}

Note: ${ }^{*} p<0.1 ; * * p<0.05 ; * * * p<0.01$ (two-sided tests), panel-corrected standard errors in parentheses. 
Table 2: ADL regressions of annual debt changes

\begin{tabular}{|c|c|c|c|c|c|c|}
\hline & Model 5 & & Model 6 & & Model 7 & \\
\hline$\overline{\Delta \text { Debt ratio }_{\mathrm{t}-1}(\mathrm{LDV})}$ & $0.208^{* * *}$ & $(0.045)$ & $0.225 * * *$ & $(0.045)$ & $0.147^{* * *}$ & $(0.058)$ \\
\hline Debt ratio $_{t-1}$ & $-0.022 * * *$ & $(0.006)$ & $-0.020 * * *$ & $(0.006)$ & $-0.040 * * *$ & $(0.010)$ \\
\hline Real GDP growth $_{\mathrm{t}}$ & $-0.294 * * *$ & $(0.081)$ & $-0.308 * * *$ & $(0.081)$ & $-0.390 * * *$ & $(0.129)$ \\
\hline Unemployment $_{\mathrm{t}}$ & $0.116^{* * *}$ & $(0.037)$ & $0.127^{* * *}$ & $(0.037)$ & $0.262^{* * *}$ & $(0.069)$ \\
\hline$\Delta$ Unemployment $_{\mathrm{t}}$ & $0.789^{* * *}$ & $(0.160)$ & $0.752^{* * *}$ & $(0.160)$ & $0.862^{* * *}$ & $(0.260)$ \\
\hline Fiscal pressure $_{t}$ & $0.004^{* * *}$ & $(0.001)$ & $0.015^{* * *}$ & $(0.003)$ & $0.003^{* * *}$ & $(0.001)$ \\
\hline Fiscal pressure $_{t-1}$ & & & $-0.009 * * *$ & $(0.003)$ & & \\
\hline LRM Fiscal pressure & & & $0.007 * *$ & $(0.003)$ & & \\
\hline Coalition government ${ }_{t}$ & -0.054 & $(0.609)$ & 0.373 & $(0.624)$ & 1.271 & $(0.811)$ \\
\hline Coalition government $t_{t-1}$ & $-1.253^{* *}$ & $(0.592)$ & $-1.623 * * *$ & $(0.608)$ & $-1.669 * *$ & $(0.772)$ \\
\hline LRM Coalition government & $-1.650 * * *$ & $(0.376)$ & $-1.612 * * *$ & $(0.377)$ & -0.467 & $(0.605)$ \\
\hline Prospective cooperation $_{t}$ & $-4.019 * * *$ & $(1.529)$ & 0.002 & $(1.642)$ & 2.924 & $(4.728)$ \\
\hline Prospective cooperation $_{\mathrm{t}-1}$ & 0.174 & $(1.534)$ & $-3.217^{*}$ & $(1.658)$ & 0.980 & $(4.674)$ \\
\hline LRM Prospective cooperation & $-4.856 * * *$ & $(1.007)$ & $-4.148 * * *$ & $(0.967)$ & 4.579 & (2.933) \\
\hline Election year ${ }_{t}$ & $-2.053^{*}$ & $(1.218)$ & $0.568^{* *}$ & $(0.285)$ & $0.886^{* *}$ & $(0.392)$ \\
\hline Election year ${ }_{\mathrm{t}-1}$ & $2.462^{* *}$ & $(1.217)$ & $0.721^{* *}$ & $(0.280)$ & $0.771^{* *}$ & $(0.383)$ \\
\hline LRM Election year & 0.516 & $(1.942)$ & $1.662^{* * *}$ & $(0.490)$ & $1.942^{* * *}$ & $=(0.647)$ \\
\hline Prospective cooperation $*$ election year ${ }_{t}$ & $3.093^{* *}$ & $(1.453)$ & & & & \\
\hline Prospective cooperation $*$ election year ${ }_{\mathrm{t}-1}$ & -2.242 & $(1.439)$ & & & & \\
\hline LRM Prospective cooperation * election year & 1.074 & $(2.315)$ & & & & \\
\hline Prospective cooperation * fiscal pressure ${ }_{t}$ & & & $-0.014^{* * *}$ & $(0.003)$ & & \\
\hline Prospective cooperation $*$ fiscal pressure ${ }_{t-1}$ & & & $0.011^{* * *}$ & $(0.003)$ & & \\
\hline LRM Prospective cooperation * fiscal pressure & & & -0.005 & $(0.004)$ & & \\
\hline Delegation index $_{t}$ & & & & & 11.229 & (24.183) \\
\hline Delegation index $t_{t-1}$ & & & & & -8.945 & $(23.602)$ \\
\hline LRM Delegation & & & & & 2.678 & (4.198) \\
\hline Prospective cooperation $*$ delegation $_{t}$ & & & & & -6.016 & $(7.700)$ \\
\hline Prospective cooperation $*$ delegation ${ }_{\mathrm{t}-1}$ & & & & & -1.156 & (7.539) \\
\hline LRM Prospective cooperation * delegation & & & & & $-8.411 *$ & $(5.040)$ \\
\hline Government duration $_{\mathrm{t}}$ & $-0.006^{*}$ & $(0.004)$ & $-0.007 * *$ & $(0.003)$ & -0.006 & $(0.005)$ \\
\hline Government duration $_{\mathrm{t}-1}$ & 0.006 & $(0.004)$ & $0.006^{*}$ & $(0.003)$ & 0.006 & $(0.005)$ \\
\hline Minority government ${ }_{t}$ & $-0.553^{*}$ & $(0.285)$ & $-0.540 * *$ & $(0.275)$ & $-1.069 *$ & $(0.567)$ \\
\hline Left cabinet share $_{t}$ & $-0.009 * *$ & $(0.003)$ & $-0.008 * * *$ & $(0.003)$ & $-0.011 * *$ & $(0.005)$ \\
\hline Presidentialism $_{t}$ & 0.021 & $(0.084)$ & 0.017 & $(0.087)$ & 0.060 & $(0.187)$ \\
\hline Federalism $_{t}$ & $-0.517 * * *$ & $(0.143)$ & $-0.498 * * *$ & $(0.144)$ & $-0.723 * * *$ & $(0.255)$ \\
\hline Bicameralism $_{\mathrm{t}}$ & $0.300^{* *}$ & $(0.152)$ & $0.264^{*}$ & $(0.149)$ & 0.445 & $(0.275)$ \\
\hline Time-trend & 0.306 & $(0.191)$ & 0.307 & $(0.191)$ & 0.291 & $(0.234)$ \\
\hline Time-trend $^{2}$ & $-0.014^{*}$ & $(0.007)$ & $-0.014^{*}$ & $(0.007)$ & -0.014 & $(0.009)$ \\
\hline Time-trend $^{3}$ & $0.000^{* *}$ & $(0.000)$ & $0.000^{* *}$ & $(0.000)$ & $0.000 *$ & $(0.000)$ \\
\hline Constant & $4.428^{* *}$ & (1.909) & $3.651^{*}$ & (1.913) & -0.298 & (3.041) \\
\hline$\overline{R^{2}}$ & 0.40 & & 0.42 & & 0.43 & \\
\hline$N$ & 1,210 & & 1,191 & & 681 & \\
\hline
\end{tabular}

Note: ${ }^{*} p<0.1 ;{ }^{* *} p<0.05 ;{ }^{* * *} p<0.01$ (two-sided tests), panel-corrected standard errors in parentheses. 
Table 3: Conditional effects of prospective cooperation

\begin{tabular}{lllllrr}
\hline & \multicolumn{2}{c}{ Short-run } & \multicolumn{2}{c}{ Long-run (LRM) } & N & Model \\
\hline Unconditional effect & $-2.679 *$ & $(1.474)$ & $-4.759^{* * *}$ & $(0.851)$ & 1,210 & 4 \\
No election year & $-4.019 * * *$ & $(1.529)$ & $-4.856^{* * *}$ & $(1.007)$ & 1,210 & 5 \\
Election year & -0.926 & $(1.728)$ & $-3.782^{*}$ & $(1.956)$ & 1,210 & 5 \\
High fiscal pressure (3 ${ }^{\text {rd }}$ quartile) & -1.693 & $(1.555)$ & $-4.692^{* * *}$ & $(0.943)$ & 1,191 & 6 \\
Medium fiscal pressure (median) & 0.004 & $(1.642)$ & $-4.148^{* * *}$ & $(0.967)$ & 1,191 & 6 \\
Low fiscal pressure (1) quartile) & 1.351 & $(1.773)$ & $-3.716^{* * *}$ & $(1.126)$ & 1,191 & 6 \\
High delegation index (max.) & -2.490 & $(2.975)$ & -2.991 & $(2.140)$ & 681 & 7 \\
Medium delegation index (median) & -0.325 & $(1.651)$ & 0.037 & $(1.118)$ & 681 & 7 \\
Low delegation index (min.) & 1.540 & $(3.125)$ & 2.644 & $(1.913)$ & 681 & 7 \\
\hline
\end{tabular}

Note: $* p<0.1 ; * * p<0.05 ; * * * p<0.01$ (two-sided tests), standard errors in parentheses.

Table 4: Time-varying effects of prospective cooperation

\begin{tabular}{|c|c|c|c|c|}
\hline \multirow{2}{*}{$\frac{\text { Period }}{1962-1972 \text { (“Bretton-Woods”) }}$} & \multirow{2}{*}{$\frac{\text { LRM (total) }}{-0.341^{* * *}(0.107)}$} & \multicolumn{2}{|c|}{ LRM (election year) } & \multirow{2}{*}{$\frac{\text { LRM (no election year) }}{-0.387^{* * *}(0.113)}$} \\
\hline & & -0.280 & $(0.796)$ & \\
\hline 1973-1989 (“Post-oil shock”) & $-0.332 * * *(0.097)$ & 0.076 & $(0.429)$ & $-0.367 * * *(0.112)$ \\
\hline 1990-1998 (“Maastricht”) & $-0.203 * * *(0.063)$ & -0.125 & $(0.322)$ & $-0.204 * * *(0.075)$ \\
\hline 1999-2007 (“Euro”) & $-0.252 * * *(0.069)$ & $-0.630 * *$ & $(0.354)$ & $-0.213 * * *(0.078)$ \\
\hline 2008-2013 (“Great Recession”) & $-0.171 * * \quad(0.078)$ & -0.064 & $(0.435)$ & $-0.165 *$ \\
\hline
\end{tabular}

Note: Standardized coefficients: $\mathrm{B}_{\mathrm{i}}=\beta_{\mathrm{i}}\left(\mathrm{s}_{\mathrm{i}} / \mathrm{s}_{\mathrm{y}}\right){ }^{*} p<0.1 ; * * p<0.05 ; * * * p<0.01$ (two-sided tests), standard errors in parentheses. Based on Models 4 and 5. 
Table 5: Regressions of average debt changes per government

\begin{tabular}{|c|c|c|c|c|c|c|}
\hline & Model 8 & & Model 9 & & Model 10 & \\
\hline$\Delta$ Debt ratio Gov_t-1 (LDV) & $0.206 * * *$ & $(0.066)$ & & & & \\
\hline Debt ratio Gov_t-1 & $-0.023 * * *$ & $(0.008)$ & $-0.021 * *$ & $(0.009)$ & $-0.028^{* * *}$ & $(0.009)$ \\
\hline Variance $\Delta$ debt ratio & & & & & $0.024 * * *$ & $(0.004)$ \\
\hline Real GDP growth & $-0.216^{*}$ & $(0.111)$ & $-0.255^{* *}$ & $(0.113)$ & $-0.506 * * *$ & $(0.176)$ \\
\hline Unemployment & $0.083^{*}$ & $(0.049)$ & $0.120 * *$ & $(0.047)$ & $0.161^{* * *}$ & $(0.060)$ \\
\hline$\Delta$ Unemployment & $1.026 * * *$ & $(0.240)$ & $0.942^{* * *}$ & $(0.243)$ & 0.324 & $(0.323)$ \\
\hline Fiscal pressure & $0.004 * * *$ & $(0.001)$ & $0.004 * * *$ & $(0.001)$ & 0.001 & $(0.001)$ \\
\hline Coalition government & -0.539 & $(0.442)$ & -0.735 & $(0.462)$ & $-1.180^{* *}$ & $(0.508)$ \\
\hline Prospective cooperation & $-3.527^{*}$ & $(1.819)$ & $-4.290 * *$ & $(1.853)$ & $-5.676^{* * *}$ & $(1.902)$ \\
\hline Government duration & 0.001 & $(0.001)$ & 0.001 & $(0.001)$ & 0.001 & $(0.001)$ \\
\hline Minority government & -0.455 & $(0.388)$ & -0.414 & $(0.403)$ & -0.365 & $(0.464)$ \\
\hline Left cabinet share & $-0.012 * *$ & $(0.005)$ & $-0.012 * *$ & $(0.005)$ & $-0.012 * *$ & $(0.005)$ \\
\hline Presidentialism & -0.052 & $(0.099)$ & -0.063 & $(0.100)$ & -0.159 & $(0.160)$ \\
\hline Federalism & $-0.442 * *$ & $(0.195)$ & $-0.465^{* *}$ & $(0.202)$ & $-0.520^{* *}$ & $(0.251)$ \\
\hline Bicameralism & $0.332 * *$ & $(0.160)$ & $0.338 *$ & $(0.175)$ & $0.503^{* *}$ & $(0.229)$ \\
\hline Time-trend & $0.363^{* *}$ & $(0.157)$ & $0.548 * * *$ & $(0.138)$ & $0.559 * * *$ & $(0.190)$ \\
\hline Time-trend $^{2}$ & $-0.017 * * *$ & $(0.007)$ & $-0.025^{* * *}$ & $(0.006)$ & $-0.024 * * *$ & $(0.007)$ \\
\hline Time-trend $^{3}$ & $0.000 * * *$ & $(0.000)$ & $0.000^{* * *}$ & $(0.000)$ & $0.000 * * *$ & $(0.000)$ \\
\hline Days in office & -0.001 & $(0.000)$ & -0.001 & $(0.000)$ & -0.001 & $(0.001)$ \\
\hline Constant & 3.432 & (2.198) & 3.297 & (2.327) & $5.188 *$ & (2.828) \\
\hline$\overline{R^{2}}$ & 0.45 & & 0.43 & & 0.51 & \\
\hline$N$ & 494 & & 496 & & 333 & \\
\hline
\end{tabular}

Note: $* p<0.1$; ** $p<0.05$; *** $p<0.01$ (two-sided tests), panel-corrected standard errors in parentheses. Unit of observation: cabinets. All variables are average values per cabinet. Only governments in office at least 6 months considered (results are robust if more short-lived governments are included, too). 
1 Allians för Sverige. 2006. Fler i arbete - mer att dela på. Valmanifest 2006. http://wwwc.aftonbladet.se/val2006/0608/23/alliansmanifest.pdf (last accessed 2016-01-07); Alliansen. 2010. Jobbmanifestet. Valmanifest 2010-2014. http://www.alliansen.se/wp-content/uploads/2014/03/Alliansensjobbmanifest-2010.pdf (last accessed 2016-01-07).

2 Bundeskanzleramt. 2008. Regierungsprogramm 2008-2013: Gemeinsam für Österreich. https://www.bka.gv.at/DocView.axd?CobId=32966 (last accessed 2016-01-07).

${ }^{3}$ Irish Government. 15 December 1994. A Government of Renewal - A Strategy for Renewal. Irish Times, p. 6.

${ }^{4}$ One explanation for the slight differences may be classification decisions of political parties (e.g., the recategorization of the Swiss SVP from an agrarian to a right-populist party in the data source of this article).

${ }^{5}$ The measure captures parties' degree of past cooperation only while participating in government. In past years when current governing parties were not in government, they are technically assigned a maximum value of $\alpha=1$. Otherwise parties' familiarity levels would be punished merely for not having participated in governing coalitions.

${ }^{6}$ The presidential systems of Cyprus and USA are continuously treated as single-party governments.

${ }^{7}$ In general, cooperation outlooks are higher at the beginning of the measurement periods due to governments consisting entirely of new parties, which have maximum cooperation prospects. As an empirical robustness test, I therefore included a dummy variable for "new governments". In addition, Model A3 in the online appendix controls for cooperation trends explicitly. These models show that both levels and changes of prospective cooperation matter for debt accumulation.

${ }^{8}$ Pooled Dickey-Fuller tests clearly reject the null hypothesis that all panels contain unit roots $(\mathrm{p}<0.000)$. DickeyFuller tests within countries cannot significantly reject the null hypothesis for some Central and Eastern European countries and for Spain. This is most likely due to the low statistical power for these cases with a smaller $\mathrm{N}$ than the older democracies. In subsequent robustness tests, excluding each of these countries makes no difference to the findings.

${ }^{9} \mathrm{p}>0.5$, calculated after Beck and Katz $(1996,9)$.

${ }^{10}$ As shown by Pesaran tests for cross-sectional dependence and Wald tests for panel heteroskedasticity.

${ }^{11}$ Some Hausman tests found significant unit heterogeneity. However, it turns out that this is mostly due to the variables federalism and bicameralism. Seldom constitutional changes lead to largely different coefficients in fixed effects within-regressions. Excluding these two variables, no need for fixed effects is indicated ( $\mathrm{p}>0.5)$.

${ }^{12}$ Government changes are identified by elections, resignation of prime ministers, coalition break-ups, lack of parliamentary support or intervention by the head of state (Armingeon et al. 2015b).

${ }^{13}$ Standard errors of the long-run multipliers (LRM) were calculated using the Bewley transformation (De Boef and Keele 2008, 191-92).

${ }^{14}$ Based on the formula for compound interest: DebtRatio ${ }_{t+20}=80\left(1+\frac{2.38}{100}\right)^{20}=128.05$

${ }^{15}$ The group difference for coalitions is: $\mathrm{E}(\Delta$ DebtRatio $\mid$ Coalition $=1)-\mathrm{E}(\Delta$ DebtRatio $\mid$ Coalition $=0)$

$=\beta_{\text {Coalition }} * 1+\beta_{\text {ProspectiveCooperation }} *$ ProspectiveCooperation $-\left(\beta_{\text {Coalition }} * 0+\beta_{\text {ProspectiveCooperation }} * 1\right)$

$=\beta_{\text {Coalition }}-\beta_{\text {ProspectiveCooperation }}(1-$ ProspectiveCooperation $)$.

16 Bäck and Lindvall (2015) also find evidence for this coalition effect in some models, but their evidence is clearly weaker. Reasons for this might be sample or operationalization differences, but a more likely reason is that they do not discern short-run and long-run coalition effects - which run in opposite directions.

${ }^{17}$ Delegation data are available only for 15 countries and two/three time points.

18 These include the use of country fixed effects or the calculation of standard errors (panel-corrected with PraisWinsten transformation, OLS standard errors, OLS country-clustered standard errors). In Jackknife analyses, the long-run effect of prospective cooperation remains significant under the exclusion of each country $(p<0.01)$. The results are also robust to the exclusion of all post-communist Central and Eastern European countries. Finally, there are no indications of multicollinearity problems among the substantive variables. See Table A3 and Figure A3 in the online appendix. 